\title{
Relation of Protein Synthesis to Plasma and Cell Amino Acids in Neonates
}

\author{
CAROLYN JOHNSON AND JACK METCOFF \\ WITH THE TECHNICAL ASSISTANCE OF JAMES GABLE \\ University of Oklahoma Health Sciences Center, Department of Pediatrics, Biochemistry and Molecular Biology, \\ Oklahoma City, Oklahoma 73190
}

\begin{abstract}
We hypothesized that more rapidly growing preterm infants would have higher rates of protein synthesis than term infants, and that protein synthesis would be more closely related to intracellular than plasma levels of amino acids. Neutrophils, used as a cell model, were isolated from 1-3 ml blood of 63 infants $27-44$ wk postconceptual age. Protein synthesis $\left({ }^{3} \mathrm{H}\right.$-leucine incorporation, $\mathrm{pmol} / \mathrm{h} / \mathrm{mg}$ DNA), and 19 amino acids in the leukocytes (nmol/mg DNA) and plasma $(\mathrm{nmol} / \mathrm{ml})$ were quantified. Protein synthesis was related inversely to birth weight and gestational age, i.e. the smaller and more preterm the infant the higher the rate of protein synthesis. Multiple regression analysis limited to six steps indicated that some plasma amino acids (Val, Ile, Phe, Asp, Ala, Tau) accounted for a significant $(p=0.03)$, but relatively small, proportion, $23 \%$, of the variance in protein synthesis. A greater proportion of the variance in protein synthesis was explained by a set of six intracellular amino acids (Leu, Met, Tyr, Gly, Ala, Tau), with $\mathrm{R}^{2}=36 \%, p=0.001$. Further, multiple regression identified specific combinations of six plasma amino acids which best explained ("predicted") the levels of each intracellular amino acid predictor of protein synthesis $\left(R^{2}=0.4-0.5, p<0.001-\right.$ $0.0001)$. Activities of some rate-limiting glycolytic enzymes, pyruvate kinase and phosphofructokinase, were correlated with protein synthesis in the leukocytes $(p=$ 0.036 , and 0.002 , respectively). Phosphofructokinase, the major regulating enzyme in glycolysis, also was negatively correlated with birth weight and gestational age. These data indicate that protein synthesis is higher in smaller neonates, and that its level can be predicted from levels of a few intracellular amino acids whose concentrations, in turn, can be predicted from specific sets of different plasma amino acids. (Pediatr Res 20: 140-146, 1986)
\end{abstract}

\section{Abbreviations}

LGA, large for gestational age

SGA, small for gestational age

AGA, appropriate for gestational age

The most rapid period of human growth occurs before birth. During the 2 nd trimester the fetus increases in weight by about $1000 \%$. After 36 wk gestation the growth rate declines somewhat,

Received April 22. 1985: accepted September 19.1985

Correspondence and reprint requests to Jack Metcoff. M.D.. George Lynn Cross Reearch Professor. The University of Oklahoma Health Sciences Center, P.O. Box 26901, Oklahoma City, OK 73190

Supported, in part, by Cooperative Agreement 58-519B-0-0930 with the USDA/ ARS. but the increment of weight is still about $10 \%$ per week. Postnatally, the rate continues to diminish, but by $4-5$ months of age birth weight is approximately doubled. This pattern of growth implies that the rate of protein synthesis must be very rapid early in gestation and postnatally to form new cells and to maintain growth of existing cells. Since fetal growth rate reaches it zenith during the 3rd trimester, one may speculate that the rate of protein synthesis also might peak then and decline thereafter. Efforts to quantify rates of protein synthesis and turnover of infants have been made from nitrogen balance measurements and studies of whole body protein turnover using stable isotopes (1-3). These measurements provide an indirect assessment of protein metabolism and requirements. Plasma amino acid patterns also have been used to estimate protein metabolism; however, while they have been shown to reflect recent dietary intake $(4,5)$, their relation to protein synthesis and to intracellular amino acid pools is largely unexplored. This study was undertaken on the hypothesis that the rate of protein synthesis would not only be greater in small preterm than term infants, but also could be predicted from the intracellular levels of some substrate amino acids.

Classically, either muscle or liver cells have been used as models for protein and energy metabolism; however a biopsy of either tissue is traumatic and not without risk in a small or sick newborn. The circulating polymorphonuclear leukocyte has been used as an alternative, viable cell model. The major metabolic pathways are present in the polymorphonuclear granulocyte and its metabolism is similar to that of other nucleated cells. It derives its energy mainly from glycolysis (6), actively incorporates amino acids for protein synthesis (7) and reflects certain genetic enzyme defects $(8)$ and nutritional biochemical changes $(9,10)$. It contains many energy-related enzymes, including pyruvate kinase and phosphofructokinase, which are rate-limiting in a major energy pathway of the fetus, glycolysis, and, in the case of pyruvate kinase, generate adenosine triphosphate. Whether the activities of these enzymes are related to the rates of protein synthesis in neonates is not known and also were investigated in this study.

\section{SUBJECTS AND METHODS}

Infants less than 44 wk ( $<308$ days) postconceptual age were eligible for study. Seriously ill infants and those requiring respiratory support were excluded. Patient demographic characteristics are described in Table 1. Gestational age was estimated by the method of Dubowitz et al. (11). Expected birth weight, adjusted for sex, parity, and race was estimated from the Brenner nomogram (12). Infants whose actual birth weight was $>500 \mathrm{~g}$ above or below the expected weight, according to the Brenner scheme, were classified as LGA or SGA, respectively. Those whose birth weights differed from the adjusted, expected weight by $\leq 500 \mathrm{~g}$ were considered AGA. At the time of study, infants 
Table 1. Patient characteristics

\begin{tabular}{|c|c|c|c|c|c|}
\hline Classification* $(n)$ & & SGA (21) & $\mathrm{AGA}(40)$ & & \\
\hline \multirow{3}{*}{$\begin{array}{l}\text { Gestational } \\
\text { Age (wk) }\end{array}$} & Range & $33-41$ & $27-41$ & & \\
\hline & Mean & 37.3 & 36.6 & & \\
\hline & Preterm† & Term & Preterm & Term & Term \\
\hline$n$ & 13 & 8 & 24 & 16 & 2 \\
\hline Mean birth wt (g) & 1571 & 2416 & 1983 & 3406 & 4200 \\
\hline Mean wt at study $(\mathrm{g})$ & 1692 & 2406 & 2196 & 3295 & 4300 \\
\hline Mean age ar study (days) & 10 & 3 & 18 & 3 & 7 \\
\hline Mean postconceptual age (days) & 254 & 280 & 253 & 281 & 287 \\
\hline Mean gestational age (weeks) & 34.9 & 39.6 & 33.5 & 39.7 & 42 \\
\hline
\end{tabular}

* Classification based on deviation of observed expected weight, adjusted for gestational age, parity, race, and baby's sex (12).

+ Preterm $=<38 \mathrm{wk}$ gestation; term $=\geq 38 \mathrm{wk}$. There were no preterm large for gestational age infants.

ranged in postnatal age from 1 day to $14 \mathrm{wk}$, with 52 babies studied during the first $2 \mathrm{wk}$ of life. The very low birth weight infants $(<1000 \mathrm{~g})$ were the oldest postnatally when studied, but still were $<44$ wk postconceptual age. Fifty-eight infants were receiving breast milk or commercial formula. Four infants (two term and two preterm, AGA) studied within $48 \mathrm{~h}$ of birth were receiving intravenous dextrose solutions. The values for protein synthesis in these infants were consistent with others of the same gestational age. One of the smallest prematures $(920 \mathrm{~g})$ was receiving only parenteral amino acid nutritional support. He had the highest value for protein synthesis in our study. Another larger premature SGA infant receiving formula with supplemental parenteral amino acid solution, also had a high value for protein synthesis. The outlying values for both babies were truncated to the upper limit of our normal frequency distribution so that these two values would not exert undue influence on the SDs of the mean protein synthesis value. Blood samples were obtained near the end of the usual between-feed interval. Informed consent was obtained from parents for all babies and the study was approved by the Institutional Review Board.

Our standardized leukocyte isolation technique $(9,13)$ has been modified to include a Ficoll-Hypaque gradient sedimentation step, to provide a more homogeneous and higher yield of granulocytes (14). One to three $\mathrm{ml}$ of heparinized blood is sedimented for 30 minutes in a $10 \%$ dextran (Sigma) solution in an ice bath. The leukocyte-rich plasma is further separated using Ficoll-Hypaque (Pharmacia Fine Chemicals). The washed leukocyte pellet is suspended in $0.16 \mathrm{M} \mathrm{KCl}$. Trypan Blue exclusion testing and Wright's staining show $>95 \%$ polymorphonuclear leukocytes, with $>97 \%$ viable cells isolated by this technique.

Protein synthesis was determined as incorporation of $4,5^{3} \mathrm{H}$ leucine at $37^{\circ} \mathrm{C}$ for 10,20 and $30 \mathrm{~min}$ into a $10 \%$ trichloracetic acid insoluble protein fraction of the granulocytes. Incorporation of the isotope remains linear during this interval. The rate is calculated from a least squares regression line fitted to the three points. The assay medium consisted of $100 \mu$ l saline containing $1 \%$ Eagle's minimum essential medium and $0.4 \%$ glucose; 100 $\mu \mathrm{l}$ of $1 \mathrm{mM} \mathrm{MgCl}$ and $0.05 \mathrm{M}$ tris- $\mathrm{HCl}(\mathrm{pH} 7.9)$; and $1 \mu \mathrm{Ci}$ of labeled amino acid in $10 \mu \mathrm{l}$ saline $(1 \mathrm{Ci} / \mathrm{mmol})$. The reaction was stopped with cold $10 \%$ trichloracetic acid and the precipitate filtered, washed, dried, and solubilized in scintillation fluid [4 $\mathrm{g}$ POP and $0.1 \mathrm{~g}$ POPOP/liter of "scintanalyzed" toluene (Fisher)] (15). The activity was counted in a Packard Scintillation Counter ( $52 \%$ efficiency) and the uptake of amino acid per hour calculated using the specific activity $(1112 \mathrm{dpm} / \mathrm{pmol})$ of ${ }^{3} \mathrm{H}$-leucine. No correction was made for the intracellular pool of leucine, but the medium concentration was more than five times that of intracellular leucine, thus providing sufficient excess to minimize possible dilution effects (16). Leukocytes have a very short life span in the circulation and minimal or undetectable protein degradation (17); therefore the incorporation of the isotope can be considered to reflect protein synthesis.

Amino acid determinations were made on a Dionex D-300 high pressure Amino Acid Analyzer with automatic program controller and a $25 \mathrm{~cm}$ cation exchange column (Pickering Laboratories no. 7050), sodium eluents, post column O-phthalaldehyde derivatization, fluorometric detection, and peak integration by a Spectra-Physics Analyzer System One. Leukocyte suspensions were freeze-thawed twice and the protein precipitated with a final concentration of $0.6 \%$ sulfosalycylic acid. Norleucine was added to the supernatant as the internal standard. Plasma was similarly prepared for analysis except the freeze-thaw cycles were omitted and the final concentration of sulfosalicylic acid was $2 \%$. Eluents were mixed in the laboratory from stock solutions supplied by Pickering Laboratories at five $\mathrm{pH}$ values ranging from 2.93 to 4.95 .

Two column temperatures, 46 and $69^{\circ} \mathrm{C}$, were used during a total analysis time of $205 \mathrm{~min}$. A standard amino acid solution was analyzed as a reference between every five samples. Cystine is not measured by this method. The resolution of glutamine, serine, and asparagine is incomplete.

Leukocyte DNA was measured by the modified diphenylamine method described by Giles and Meyers (18). Leukocyte amino acid contents and protein synthesis were referenced to DNA content. To express relative intracellular amino acid concentrations, intracellular water was computed from the DNA content based on simultaneous measurements of intracellular water and DNA made in a separate study of leukocytes isolated from 15 normal neonates by a modification of the method of Baron and Ahmed (19), using ${ }^{14} \mathrm{C}$ inulin to correct for "trapped" water retained between pelleted cells. The intracellular amino acid concentrations of the study babies were computed from the regression of intracellular water on DNA derived from the separate study.

After sonication of an aliquot of cell suspension (Braun Sonic, $199 \mathrm{~W}, 10 \mathrm{~s}$ ), the activities of pyruvate kinase and phosphofructokinase were measured spectrophotometrically at $30^{\circ} \mathrm{C}$ in a Gilford 250 spectrophotometer using a $1 \mathrm{~cm}$ light path with microcuvettes and total volume of $215 \mu \mathrm{l}$. Determination of pyruvate kinase activity was based on the coupled enzymatic conversion of phosphoenolpyruvate to pyruvate by pyruvate kinase and subsequent reduction of pyruvate to lactate. Phosphofructokinase determination was based on the coupled reactions of fructose-6-phosphate to fructose 1,6 diphosphate by phosphofructokinase, conversion of fructose 1,6 diphosphate to dihydroxyacetone by aldolase and triose phosphate isomerase, and then reduction of dihydroxyacetone to glycerol-1-phosphate. After addition of sample to the appropriate reaction mixture the change in light absorption at $340 \mu$ with oxidation or reduction of NADPH was recorded for 3 min using a strip chart recorder (Gilford 6051). The methods have been slightly modified from. those reported from this laboratory (20).

Data were examined initially by a univariate frequency distribution analysis to detect outliers, all of which were checked. Three protein synthesis, four plasma and two cell amino acic measurements were truncated at the upper $2 \%$ of the distribution 
to bring them closer to the range of the remaining values. All other data were untruncated. Two-tailed $t$ tests, analysis of variance, product: moment correlations and multiple regression analyses were performed using Statisical Analysis Systems programs (21) with an IBM 3801 computer.

\section{RESULTS}

Protein synthesis. Complete data for protein synthesis were available in all 63 infants. Figure 1, a best fit curve drawn by computer, shows the inverse, polynomial relationship between birth weight and protein synthesis. The plot is a cubic regression and the equation is given in the legend of Figure 1. When the data were analyzed by type of baby (class = premature, SGA, term), the rate of protein synthesis was significantly higher ( $p=$ 0.0097 ) in preterm and SGA infants in comparison with term $\mathrm{AGA}$ and LGA infants (mean $\pm \mathrm{SD}=4740 \pm 2327, n=24$ and $4356 \pm 2266, n=21$ versus $2717 \pm 1255, n=18$, respectively). The birth weights of the SGA and preterm infants were similar (1893 and 1983) and significantly less than the term babies (3496 $\mathrm{g})$. The mean gestational age of the SGA infants was significantly greater than the preterms ( 36.7 versus $33.5 \mathrm{wk}$ ) but less than the AGA term babies ( $40.0 \mathrm{wk}$ ). There was a significant negative correlation between birth weight and protein synthesis $(r=$ $-0.49, p=0.0001)$. Gestational age and weight at study also

Table 2. Leukocyte cell water*

\begin{tabular}{lcccccc}
\hline & \multicolumn{5}{c}{ Wt } \\
\cline { 2 - 6 } & & & & & ICW & \\
& Wet & $\begin{array}{c}\text { Dry } \\
(\mathrm{mg})\end{array}$ & $\begin{array}{c}\text { ECW } \\
(\mu \mathrm{g})\end{array}$ & $\begin{array}{c}\text { ICW } \\
(\mu \mathrm{g})\end{array}$ & $\begin{array}{c}\text { DNA } \\
(\mu \mathrm{l} / \mathrm{mg})\end{array}$ & $\% \mathrm{ICW}$ \\
\hline Mean & 7.77 & 2.41 & 0.09 & 5.27 & 77.7 & 68.1 \\
SD & & & & & 8.9 & 5.3 \\
\hline
\end{tabular}

* Fifteen normal neonates. Birth weight $=3378 \pm 370$ (SD) g. Gestational age $=39.3 \pm 1.3(\mathrm{SD}) \mathrm{wk}$. Post conceptual age at study $=277.5$ $\pm 9.6(\mathrm{SD})$ days. ECW, extracellular water $=$ "trapped" water. ICW, intracellular water $=$ cell water, corrected for trapped water. \% intracellular water $=$ intracellular water as percentage of wet weight. were inversely correlated with protein synthesis $(r=-0.44, p=$ 0.0001 , and $r=-0.49, p=0.0001$, respectively). However, when protein synthesis for each type (class) of baby was adjusted for the combined influences of birth weight, gestational age, and weight at time of study, the differences between the groups were not statistically significant, indicating that these covariates exert an important influence on the rate of protein synthesis.

Intracellular water. Cellular water is slightly higher in leukocytes of infants (Table 2) than in adults (22), 68.1 versus $66.8 \%$ of wet weight corrected for trapped water. Intracellular water is correlated with DNA content: intracellular water $(\mu \mathrm{l})=0.530+$ 0.074 DNA $(\mu \mathrm{g}) ; n=15, r=0.85, p=0.0001$.

Table 3. Plasma and cell amino acid concentrations

\begin{tabular}{|c|c|c|c|c|}
\hline \multirow{3}{*}{ Amino acids } & \multicolumn{2}{|c|}{ Plasma } & \multicolumn{2}{|c|}{ Leukocyte } \\
\hline & Mean & SE & Mean & SE \\
\hline & \multicolumn{2}{|c|}{$\begin{array}{c}\mathrm{nmol} / \mathrm{ml} \\
(n=57)\end{array}$} & \multicolumn{2}{|c|}{$\mathrm{nmol} / \mathrm{mg} \mathrm{DNA}$} \\
\hline Threonine & 122 & 9 & 30 & 4 \\
\hline Valine & 103 & 6 & 7 & 1 \\
\hline Methionine & 34 & 3 & 3 & 0.5 \\
\hline Isoleucine & 37 & 3 & 14 & 3 \\
\hline Leucine & 73 & 4 & 20 & 3 \\
\hline Phenylalanine & 46 & 2 & 6 & 1 \\
\hline Tryptophane & 17 & 2 & 0.2 & 0.1 \\
\hline Lysine & 104 & 7 & 29 & 4 \\
\hline Histidine & 51 & 3 & 21 & 4 \\
\hline Arginine & 49 & 4 & 11 & 2 \\
\hline Aspartic acid & 10 & 1 & 69 & 7 \\
\hline GLS* & 449 & 24 & 145 & 16 \\
\hline Glutamic acid & 54 & 5 & 208 & 24 \\
\hline Citrulline & 13 & 1 & 0.6 & 0.2 \\
\hline Glycine & 207 & 10 & 171 & 22 \\
\hline Alanine & 197 & 15 & 57 & 6 \\
\hline Tyrosine & 84 & 6 & 7 & 1 \\
\hline Ornithine & 67 & 6 & 52 & 9 \\
\hline Taurine & 48 & 4 & 1334 & 93 \\
\hline
\end{tabular}

* Glutamine, asparagine, serine.

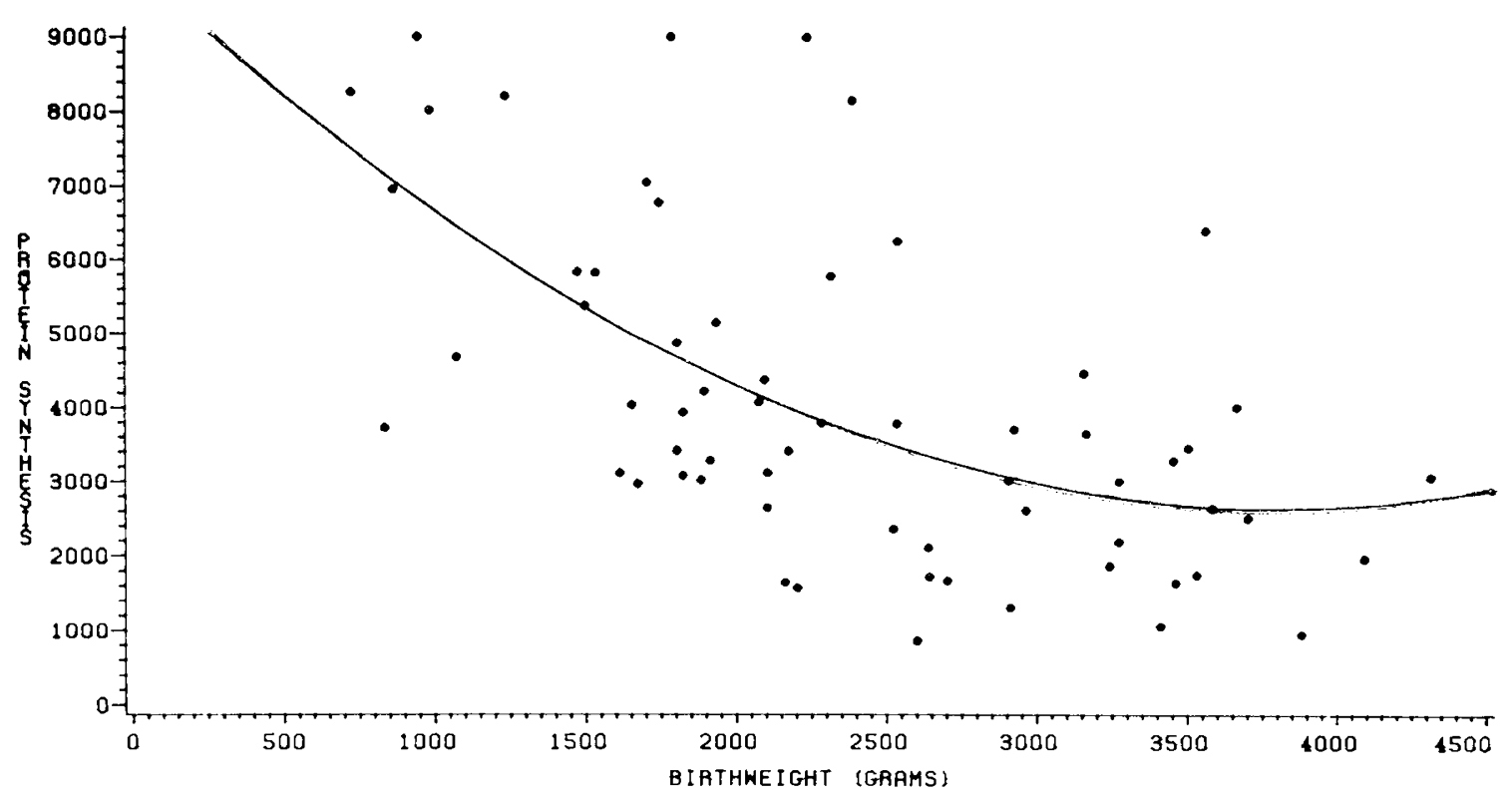

Fig. 1. Protein synthesis versus birth weight. Protein synthesis was measured as incorporation of $4,5-{ }^{3} \mathrm{H}$-leucine, in vitro by viable, isolated leukocytes. Each point represents one infant. The curve represents a best-fit polynomial regression: protein synthesis $=9978-3.78$ (birth weight) + 0.001 (birth weight) ${ }^{2}-9.58$ (birth weight) $)^{3} . \mathrm{R}^{2}=0.36: p=0.0001: n=63$. The mean value for protein synthesis was $4067 \pm 1763(\mathrm{SD}) \mathrm{pmol} / \mathrm{h} /$ $\mathrm{mg}$ DNA. The plot illustrates an inverse relationship between protein synthesis and birth weight. The mean birth weight and gestational age were $2385 \pm 884 \mathrm{~g}(\mathrm{SD})$ and $36.4 \pm 3.6 \mathrm{wk}$, respectively. The mean weight at the time of study (postconceptional age $=266$ days) was $2466 \pm 805 \mathrm{~g}$. 
Amino acids in plasma and cells. Mean values for the intracellular and plasma amino acid levels, obtained from the same blood sample in 57 of the 63 infants, are given in Table 3 . Except for methionine, which was lower in SGA than AGA term babies (1.9 versus $4.9 \mathrm{nmol} / \mathrm{mg}$ DNA, $p=0.023$ ), cell amino acid values of the four types of babies were not signficantly different and the data were combined for further analysis.

Figure 2 shows an overlay plot of the intracellular and extracellular (plasma) amino acid patterns. Intracellular concentrations ( $\mathrm{nmol} / \mathrm{ml}$ intracellular water) are higher for most amino acids compared to their plasma concentrations. The cellular concentration of the nonprotein amino acid, taurine (not illustrated), was about 100 times its plasma concentration. The dispensable amino acids glutamine, serine, asparagine, glycine, alanine, glutamic, and aspartic acids also were about three to 100 times their concentrations in plasma. The concentrations of the essential branched-chain amino acids, leucine and isoleucine, were about three times higher in the cells than in plasma. The intracellular concentration of valine was slightly $(p=0.052)$ lower than its plasma level. Of 361 possible simple correlations between levels of amino acids in plasma and cells, there were 34 significant correlations ( 18 would be expected by chance), but only four were self-correlated on both sides of the cell membrane: histidine, aspartic acid, tyrosine, and ornithine. Plasma alanine was the only extracellular amino acid whose level was correlated significantly (product:moment) with protein synthesis ( $r=$ $-0.26, p=0.03$ ).

Relation of protein synthesis to plasma amino acid pools. A multiple regression analysis, limited to six steps, with protein synthesis as the dependent variable and 19 plasma amino acids as the independent variables showed that a combination of the concentrations of valine, isoleucine, phenylalanine, aspartic acid, alanine, and taurine accounted for a small $\left(\mathrm{R}^{2}=0.23\right)$, but statistically significant $(p=0.027)$, proportion of the variance in protein synthesis (Table 4).

Relation of protein synthesis to intracellular amino acids. The six-step multiple regression analysis with protein synthesis as the dependent variable and the intracellular amino acids as the independent variables selected leucine, methonine, tyrosine, glycine, alanine, and taurine as satisfying the model. The combination ("set") of amino acids accounted for $36 \%$ of the variance in protein synthesis $(p=0.001)$. The regression equation for the model is also given in Table 4.

Relation of intracellular to plasma amino acids. To explore the relationships of intracellular to plasma amino acid pools, each of the six intracellular amino acids selected by the model

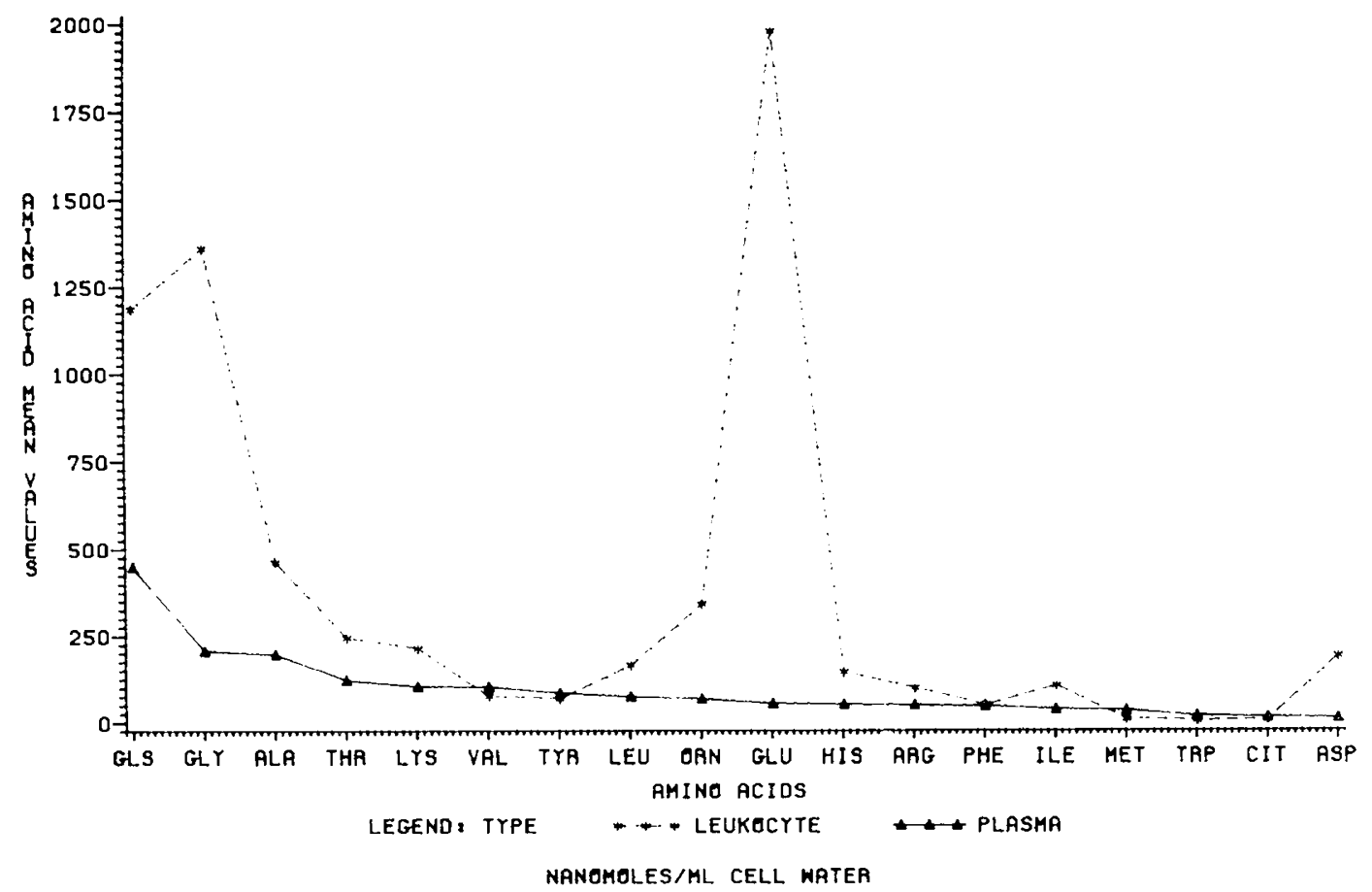

Fig. 2. Intracellular versus plasma amino acids. Cell concentrations are expressed as $\mathrm{nmol} / \mathrm{ml}$ intracellular water. Intracellular water was determined by dry weight corrected for "trapped" water using ${ }^{14} \mathrm{C}$ inulin. Each point represents the mean value for paired analysis of each amino acid in the 57 babies. Univariate analysis was used to assess the difference between the cell and plasma amino acid levels. The overlay plot was drawn by computer. All infants were less than 308 days postconceptual age with an average birth weight $=2431 \pm 887$ (SD) $\mathrm{g}$ and gestational age $==$ $36.6 \pm 3$ (SD) wk. Cell versus plasma concentrations of phenylalanine and tyrosine were not significantly different. $p$ values for differences: valine $=0.052$, citrulline $=0.0006$, arginine $=0.0002$, all others $=0.0001$.

Table 4. Multiple regression analysis of relation of protein synthesis to plasma and intracellular amino acids*

Relation of protein synthesis to plasma amino acids

Protein synthesis $=4925-14(\mathrm{VAL})+45(\mathrm{ILE})+42(\mathrm{PHE})-73(\mathrm{ASP})-9(\mathrm{ALA})-11(\mathrm{TAU})$

$$
\mathrm{R}^{2}=0.23, p=0.027, n=59
$$

Relation of protein synthesis to intracellular amino acids

Protein synthesis $=3853+84($ LEU $)-222($ MET $)-39($ TYR $)+9($ GLY $)-32($ ALA $)-0.5($ TAU $)$

$$
\mathrm{R}^{2}=0.36, p=0.001, n=54
$$

\footnotetext{
* Protein synthesis in pmol/h/mg DNA: plasma amino acids in $\mathrm{nmol} / \mathrm{ml}$; Leukocyte amino acid concentrations in $\mathrm{nmol} / \mathrm{mg} \mathrm{DNA}$.
} 
Table 5. Prediction of intracellular amino acids by plasma amino acid levels*

\begin{tabular}{|c|c|c|c|c|c|c|}
\hline & \multicolumn{6}{|c|}{ Intracellular amino acid predictors of protein synthesis $\dagger$} \\
\hline & Leucine & Methionine & Tyrosine & Glycine & Alanine & Taurine \\
\hline $\begin{array}{l}\text { Plasma amino acid } \\
\text { predictors of the in- } \\
\text { tracellular amino } \\
\text { acid levels }\end{array}$ & $\begin{array}{l}\text { Methionine } \\
(-) \text { Phenylalanine } \\
(-) \text { Arginine } \\
\text { (-) Citrulline } \\
\text { Ornithine } \\
\text { Taurine }\end{array}$ & $\begin{array}{l}\text { (-) Tryptophane } \\
\text { (-) Histidine } \\
\text { (-) Arginine } \\
\text { (-) Glutamic Acid } \\
\text { (-) Citrulline } \\
\text { Taurine }\end{array}$ & $\begin{array}{l}\text { Isoleucine } \\
\text { Lysine } \\
\text { Histidine } \\
\text { (-) Arginine } \\
\text { (-) Glycine } \\
\text { (-) Citrulline }\end{array}$ & $\begin{array}{l}(-) \text { Valine } \\
\text { Methionine } \\
\text { Lysine } \\
\text { (-) Histidine } \\
\text { Tryptophane } \\
\text { Taurine }\end{array}$ & $\begin{array}{l}\text { Met'aionine } \\
\text { (-) Phenylalanine } \\
\text { Lysine } \\
\text { Glutamic Acid } \\
\text { (-) Citrulline } \\
\text { Taurine }\end{array}$ & $\begin{array}{l}\text { Isoleucine } \\
\text { Lysine } \\
(-) \text { Histidine } \\
\text { (-) Arginine } \\
\text { (-) Aspartic Acid } \\
\text { Glycine }\end{array}$ \\
\hline $\mathrm{R}^{2}$ & 0.49 & 0.44 & 0.45 & 0.39 & 0.38 & 0.45 \\
\hline$p$ & 0.0001 & 0.0002 & 0.0001 & 0.0010 & 0.0011 & 0.0001 \\
\hline
\end{tabular}

* Stepwise multiple regression analysis with 19 plasma amino acids as independent variables and each of the intracellular amino acid predictors of protein synthesis as a dependent variable. The group of plasma amino acids selected by the model for each intracellular predictor is listed below that intracellular amino acid. The negative (-) sign indicates a negative partial regression coefficient for that amino acid. $p=$ level of significance for prediction of the model (intracellular amino acid) by the set of independent variables (extracellular amino acids).

$+n=54$ babies with complete data.

as predictive of protein synthesis, was used as the dependent variable in a similar multiple regression analysis with the 19 plasma amino acids as the independent variables. For each of the six intracellular predictors of protein synthesis, the model selected different groups of six plasma amino acids which accounted for a statistically significant proportion of the variance of that single intracellular amino acid. Results are shown in Table 5. Plasma levels of lysine, histidine, arginine, citrulline, and taurine recurred with the greatest frequency, e.g. in four of the six sets of predictors of the intracellular amino acid levels most closely associated with protein synthesis. Thirty-eight to $49 \%$ of the variance in the levels of intracellular leucine, methionine, tyrosine, glycine, alanine, and taurine was accounted for by the different combinations of six plasma amino acids. None of the intracellular amino acids was self-represented among the set of six plasma amino acids which together accounted for a significant proportion of its variance.

Leukocyte glycolytic enzymes related to protein synthesis. Sufficient cell suspension was available to determine activities of pyruvate kinase in 38 infants and phosphofructokinase in 36 of the 63 infants. The activities of both enzymes were positively correlated with protein synthesis $(r=0.34, p=0.036$, and $r=$ $0.50, p=0.002$, respectively) in these babies. Birth weight and gestational age were correlated negatively $(r=0.38, p=0.02$ and $r=-0.35, p=0.04$, respectively) with activity of leukocyte phosphofructokinase, which catalyzes the major rate-limiting step in glycolysis.

\section{DISCUSSION}

Protein synthesis. Our data show that the lower the birth weight, the higher the rate of protein synthesis, as measured in a cell model, the granulocyte. The relationship between birth weight and protein synthesis is nonlinear. Given the interdependence of birth weight and gestational age, the inverse relationship found between protein synthesis and length of gestation is not unexpected. That protein synthesis is also related inversely to postconceptual age is consistent with data from animal work (23) and stable isotope $\left({ }^{15} \mathrm{~N}\right)$ studies of whole body protein synthesis in eight preterm infants by Nissim et al. (24). Our results also are consistent with those of Pencharz et al. (25) who observed increased rates of whole body protein synthesis $\left({ }^{15} \mathrm{~N}\right)$ in 40 preterm infants, half being SGA. Among the 20 AGA infants, the smaller (birth weight $<1500 \mathrm{~g}$ ) and more immature (gestational age $\sim 28 \mathrm{wk}$ ) had somewhat higher $(\sim 10 \%)$ rates of whole body protein synthesis than the larger (birth weight $>1500 \mathrm{~g}$ ), more mature (gestational age $\sim 33 \mathrm{wk}$ ) infants (Table 4 of Ref.
25). However, they did not find a statistically significant correlation between birth weight and whole body protein turnover. Their data indicated that whole body protein synthesis, breakdown, and nitrogen flux were increased in SGA (compared to AGA) infants; however, the difference in nitrogen retention or growth rate between their two groups was not statistically signifcant $(p>0.05)$. We also noted a significantly higher rate of protein synthesis in preterm AGA infants and in the small group of fetally malnourished, term or near term infants compared to appropriately grown term babies. Covariance analysis indicated that the difference in rate of protein synthesis between the smaller and larger babies was dependent on the combined influences of birth weight, gestational age, and weight at the time of study. The possible difference in our results relating protein synthesis to birth weight and intrauterine nutritional status may be methodologic and reflect the different parameters measured. We measured protein synthesis in an in vitro cell model, while Pencharz et al. (25) studied total body nitrogen flux in vivo. Whether the rate of protein synthesis in granulocytes is similar to protein synthesis rates in major organs, such as liver or muscle, or in the whole body, is uncertain. However $25 \times 10^{8}$ granulocytes are estimated to be produced in the bone marrow $/ \mathrm{kg} /$ day in adult men. The cell turnover rate is approximately $500 \%$ per day compared to $10 \%$ for liver. Ten billion $\left(10^{9}\right)$ leukocytes weigh $\sim 0.5 \mathrm{~g}$ and contain about $20 \%$ protein, hence their incorporation of protein is approximately $17.5 \mathrm{~g} /$ day in a $70 \mathrm{~kg}$ man or approximately $4 \mathrm{~g} /$ day in an infant, an amount roughly equivalent to the daily synthesis of plasma albumin. Because of the rapid turnover, protein degradation appears to be negligible in leukocytes, relative to protein synthesis (17); therefore the rate of incorporation of a labeled amino acid into newly synthesized protein would not be affected significantly by dilution of the pool from protein degradation. Estimations of whole body protein synthesis from distribution and excretion of stable isotopes are dependent upon several assumptions which are difficult to validate and are generally considered to underestimate absolute rates of protein synthesis by $10-20 \%(17,26)$.

Amino acids and protein synthesis. Our leukocyte results indicate that the rate of protein synthesis was more closely related to a set of intracellular amino acid levels than to a set of plasma amino acid levels. Why this particular set of intracellular amino acids (Table 4) was selected by the program to satisfy the model is not evident at this time. However, each of the amino acids comprising the set is known to have some physiological importance. For example, leucine, a branched-chain $\alpha$-keto amino acid, is considered to be an important regulator of protein synthesis. Studies by Goldberg and Tischler (27), Adibi (28), and 
Buse and Reid have shown that leucine stimulates protein synthesis in various rat tissues, possibly by facilitating translation. Tyrosine, another component of the set of intracellular amino acid predictors of protein synthesis, is considered a conditionally essential amino acid for human neonates because of the slow maturation of hepatic phenylalanine hydroxylase which converts phenylalanine to tyrosine. Alanine is considered a major gluconeogenic amino acid because of its transamination to form pyruvate and subseqeunt entry into the Krebs cycle via acetyl CoA. Glycine, another of the intracellular predictors of protein synthesis, occasionally may be limiting because endogenous glycine production in preterm infants on a limited glycine intake may be insufficient to meet demands (30). Infants fed supplemental glycine were reported to have improved growth (31). The biologic significance of taurine, also selected by the program, is not yet clear. Although not a constituent of proteins, it is present in very high concentrations in liver, brain, and muscle, and may have an important biologic function to protect cell membranes against oxidants and reduced oxygen molecules (32). It may be a conditionally essential amino acid for preterm infants, who may develop abnormal electroretinograms after prolonged treatment with total parenteral nutrition solutions or formulae lacking taurine. This retinal-response defect can be reversed by administration of taurine (33).

Winkler et al. (7) have shown that incorporation of a labeled amino acid into protein in human granulocytes can be altered by the addition of a mixture of amino acids into the incubation medium, probably by competitive membrane transport. That the levels of the six intracellular amino acid predictors of protein synthesis in our infants could, in turn, be predicted by specific, apparently unrelated, groups of plasma amino acids suggests that the extracellular amino acids might affect the intracellular concentrations of these amino acids indirectly by altering their transport into, or metabolism by, the cell. It is conceivable that in vivo excesses or imbalances of certain nutrients (e.g. amino acids) in plasma could, through an effect on membrane transport, result in relative intracellular substrate excesses or limitations of other amino acids. The fact that none of the predictor intracellular amino acids was represented among the plasma amino acids which largely accounted for its variance indicates that there is not a simple direct relation between the intracellular and plasma levels of an amino acid.

Our results demonstrate that measurements of plasma amino acid concentrations alone, are not likely to reflect either levels of intracellular amino acids or of protein synthesis; however, combinations of intracellular amino acids appear to account for a significant proportion of the variance in protein synthesis in neonates, as well as in adults, although a different set of cell amino acids comprise the predictors for adults (22). Combinations of certain plasma amino acid levels may prove useful, however, for predicting the intracellular levels of those amino acids which are statistically most closely associated with protein synthesis.

Glycolytic enzymes. The cytosolic glycolytic enzymes, pyruvate kinase and phosphofructokinase, were correlated directly with protein synthesis, and inversely with birth weight and gestational age. Pyruvate kinase and phosphofructokinase catalyze two of the three rate-limiting steps of glycolysis, the major energyproducing pathway in the leukocyte. Both plasma and intracellular alanine was found to be negatively correlated with protein synthesis in these infants, and alanine is known to inhibit to both pyruvate kinase and phosphofructokinase activity (34). For example, the maximal enzyme velocity for pyruvate kinase in leukocytes of pregnant women is inhibited by alanine (35). Fructose diphosphate normally stimulates the enzyme and can overcome the inhibition by alanine; however, this response is less effective in the leukocyte enzyme from mothers carrying fetally malnourished bäbies, which suggests an alteration in the protein structure of the enzyme (35).

\section{SUMMARY}

With polymorphonuclear leukocytes as the model, the rate of protein synthesis in neonates is inversely related to birth weight, gestational age, and weight at time of study. The activities of the glycolytic enzymes pyruvate kinase and phosphofructokinase also are inversely related to protein synthesis. Phosphofructokinase activity is correlated negatively with both birth weight and gestational age. A significant proportion of the variance in protein synthesis can be predicted from a combination of the levels of six intracellular amino acids (leucine, methionine, tyrosine, glycine, alanine, and taurine). Specific, but different, sets of plasma amino acid levels account for a significant proportion of the variance of each of these predictor intracellular amino acid concentrations.

\section{REFERENCES}

1. Pencharz B, Steffee WD, Cochran W, Scrimshaw NS, Rand WM, Young VR 1977 Protein metabolism in human neonate: Nitrogen balance studies. estimated obligatory losses of nitrogen and whole body nitrogen turnover. Clin Sci Mol Med 52:485-498

2. Waterlow JC 1975 Protein turnover in the whole body. Nature 253:157

3. Duffy B, Gunn T, Collings J, Pencharz P 1981 The effect of varying protein quality and energy intake on the nitrogen metabolism in parenterally fed very low birth weight infants. Pediatr Res 15:1040-1044

4. Anderson GH, Bryan H, Jeejecbhoy KN, Corey P 1977 Dose-response relationship between amino acid intake and blood levels in newborn infants. Am J Clin Nutr 30:1110-1121

5. Valman HB, Brown R, Palmer T, Oberholzer V, Levin B 1971 Protein intake and plasma amino acids of infants of low birthweight. Br Med J 25:789-791

6. Beck WS 1958 The control of leukocyte glycolysis. J Biol Chem 232:251-283

7. Winkler K. Heller Schoch G, Neth R 1972 Protein synthesis in human leukocytes IV. Mutual inhibition of amino acid incorporation by amino acids in cell suspension and cell free systems. Z Physiol Chem 353:787-792

8. Brewster M 1981 Leukocyte enzymes in birth defects-a review. Ann Clin Lab Sci 2:146-151

9. Yoshida T. Metcoff J, Frenk S. DeLa Pena C 1967 Intermediary metabolites and adenine nucleotides in leukocytes of children with protein-caloric malnutrition. Nature 214:525-526

10. Patrick J, Golden M 1977 Leukocyte electrolytes and sodium transport in protein energy malnutrition. Am J Clin Nutr 30:1478-1481

11. Dubowitz L, Dubowitz. V, Goldberg C 1970 Clinical assessment of gestational age in the newborn infant. J Pediatr $77: 1-10$

12. Brenner WE. Edelman DA. Hendricks CH 1976 A standard of fetal growth for the USA. Am J Obstet Gynecol 126:555-564

13. Metcoff J, Costiloe JP, Crosby W, Bentle L, Seshachalem D, Sandstead H, Bodwell C. Weaver F, McClain P 1981 Maternal nutrition and fetal outcome. Am J Clin Nutr 34:708-721

14. Boyum A 1968 Isolation of mononuclear cells and granulocytes from human blood. Scand J Clin Invest 211(suppl 97):77-89

15. Metcoff J, Wikman-Coffelt J, Yoshida T, Bernal A. Rosado A, Yoshida P. Urrusti J, Frenk S, Madrazo R, Velasco L, Morales M 1973 Energy metabolism and protein synthesis in human leukocytes during pregnancy and in the placenta related to fetal growth. Pediatrics 51:866-876

16. Rannels DE. Wartell SA. Watkins CA 1982 The measurement of protein synthesis in biological systems. Life Sci 30:1697-1790

17. Waterlow JC, Garlick PJ, Millward DJ 1978 Protein turnover in Mammalian Tissues and in the Whole Body. Elsevier North Holland Press New York, pp 271-275, 474 .

18. Giles KW, Myers A 1965 An improved diphenylamine method for the estimation of deoxyribonucleic acid. Nature 206:93-95

19. Baron DN, Ahmed SA 1969 Intracellular concentrations of water and of the principal electrolytes determined by analysis of isolated human leukocytes. Clin Sci 37:205-219

20. Metcoff J 1980 Maternal nutrition and fetal development. J Early Human Dev 4:119-120

21. SAS Users Guide 1982 SAS Institute Inc., Cary, NC

22. Metcoff $J 1985$ Intracellular amino acid levels as predictors of protein synthesis. J Am Coll Nutr (in press)

23. Garlick PJ. Millward DJ, James WPT. Waterlow JC 1975 The effect of protein deprivation and starvation on the rate of protein synthesis in the tissuc of the rat. Biochem Biophys Acta 414:71-84

24. Nissim I, Yudkoff M. Pereira G. Segal S 1983 Effects of conceptual age and dietary intake on protein metabolism in premature infants. J Pediatr Gastroenterol Nutr 2:507-516

25. Pencharz PB. Masson M. Desgranges F, Papageorgiou A 1981 Total body protein turnover in the human premature neonate: effects of birthweight. intrauterine nutritional status and diet. Clin Sci 61:207-215

26. Waterlow JC. Golden M. Picou D 1977 The measurement of rates of protein turnover, synthesis and breakdown in man and the effects of nutritional status and surgical injury. Am J Clin Nutr 30:1333-1339 
27. Goldberg A, Tischler ME 1981 Regulatory effects of leucine on carbohydrate and protein metabolism and clinical implications of branched chain amino and ketoacids. In: Walser M. Williamson Jr (eds). Elselvier North Holland Press, New York, pp 205-216

28. Adibi SA 1976 Metabolism of branched-chain amino acids in altered nutrition. Metabolism 25:1287-1302.

29. Buse M, Reid SS 1975 Leucine-a possible regulator of protcin turnover in muscle. J Clin Invest 56:1250-1261

30. Jackson AA, Shaw JCL, Barber A, Golden MHN 1981 Nitrogen metabolism in preterm infants fed human donor breast milk: the possible essentiality of glycine. Pediatr Res 15:1454-1461

31. Snyderman SE. Holt LE Jr, Dancis J, Roitman E, Boyer A, Balis ME 1962
"Unessential" nitrogen: a limiting factor for human growth. J Nutr 78:5772

32. Gaull GE 1985 Taurine is a conditionally essential nutrient in man. J Am Coll Nutr (in press)

33. Ament ME, Geggel HS, Heckenlively JR, Martin DA, Koppl J 1985 Taurine supplementation in infants receiving long term total parenteral nutrition. $J$ Am Coll Nutr (in press)

34. Scrutton FMC, Utter MF 1968 Regulation of glycolysis and gluconeogenesis in animal tissues. Ann Rev Biochem 37:249-302

35. Mameesh MS, Metcoff J, Costiloe P, Crosby W 1976 Kinetic properties of pyruvate kinase in human maternal leukocytes in fetal malnutrition. Pediatr Res 10:561-565 